\title{
Performance and emission analysis of multicylinder common rail direct injection diesel engine powered with blends of tyre pyrolysis oil-ethanol diesel
}

\author{
S. V. Khandal*, T.M. Yunus khan**, Irfan Anjum Badruddin***, Sarfaraz Kamangar***, \\ C. Ahamed Saleel***, Maughal Ahmed Ali Baig**** and Salman Ahmed N.J.***** \\ * Department of Mechanical Engineering, Sanjay Ghodawat University, Kolhapur, Maharashtra, India \\ ** Research Center for Advanced Materials Science (RCAMS), King Khalid University, Abha, 61413, Asir, Kingdom of Saudi Arabia \\ *** Department of Mechanical Engineering, College of Engineering, King Khalid University, Abha 61421, Kingdom of Saudi Arabia \\ **** Department of Mechanical Engineering, CMR Technical Campus, Hyderabad, India \\ ***** Department of Mechanical and Industrial Engineering, Sultan Qaboos University, Muscat, Oman \\ **** Corresponding Author: mabaig09@gmail.com
}

$\begin{array}{ll}\text { Submitted } & : 07 / 09 / 2019 \\ \text { Revised } & : 30 / 11 / 2020 \\ \text { Accepted } & : 06 / 12 / 2020\end{array}$

\begin{abstract}
This paper mainly focuses on optimal replacement of diesel by Tyre Pyrolysis Oil-Ethanol blends to run a common rail direct injection (CRDI) multicylinder engine and compare the results with neat diesel fuel operation results at $1500 \mathrm{rpm}$. The engine was operated at different loads and speeds. From the experimental study, decrease in brake thermal efficiency (BTE) and oxides of nitrogen (NOx) emission with increase in carbon monoxide (CO), hydrocarbon (HC), and smoke emission was observed for blends as compared to diesel fuel. Further, it was also observed that increase in speed from $1200 \mathrm{rpm}$ to $1800 \mathrm{rpm}$ yielded higher BTE with decrease in CO, HC, and smoke emission. But a slight increase in NOx, peak pressure (PP), and heat release rate (HRR) was reported at higher speed as compared to lower speeds. Beyond engine speed of $1800 \mathrm{rpm}$, knocking was observed.
\end{abstract}

Keywords: Tyre pyrolysis oil (TPO); Common rail direct injection (CRDI) engine; Ethanol; Engine performance.

\section{INTRODUCTION}

Fast depletion of diesel besides stringent emissions norms being implemented by authorities of various countries around the globe has pushed researchers to look into feasible solutions to aforesaid problems of diesel engines (Dawodu et al., 2014; Afzal et al. 2018 \& Khan et al., 2014). These two problems have boosted the research in the field of alternate fuels to replace diesel (Alenezi \& Al-Anzi, 2013 \& Avulapati et al., 2016). In recent years, a lot of research activity is being carried out to recover energy from waste materials such as rubber and plastics that have high energy density (Wang et al., 2010). The waste from tyres and tubes of automotive vehicles poses big 
environmental problem as it is not biodegradable (Jang et al., 1998). Pyrolysis has been regarded as a potential way towards sustainable economy for management of this type of waste (Martinez et al., 2020). Pyrolysis of tyres could minimize the dependency on fossil fuels besides addressing the concern related to climate change (Antoniou et al., 2013; Martínez et al., 2020). Pyrolysis is a thermochemical process, which converts waste to useful energy under oxygen free environment (Elbaba et al., 2012), and this process was demonstrated by many researchers (Murugan et al., 2008 \& Sharma et al., 2013). The end product of tyre pyrolysis process yields three valuables: Tyre pyrolysis oil (TPO), pyro-gas, and carbon black (Arya et al., 2020). TPO alone cannot be used directly in diesel engine without its proper upgrading (Aydin et al., 2012, Ahoor et al., 2014 \& Martínez 2014 et al.). The cetane number of TPO is below 30, which is an important fuel property for ignition of fuel (Hossain et al., 2013 \& Van de Beld et al., 2013). TPO can be blended with diesel, which improves the cetane number, and then can be used in existing diesel engine (Murugan et al., 2008 \& Frigo et al., 2014). Hariharan et al. (2013) studied the effect of diethyl ether on the performance of diesel engine run with TPO and reported 5\% reduction in formation of oxides of nitrogen (NOx) as compared to diesel engine run with neat diesel. Different approaches have been reported on utilization of TPO in diesel engine like blending TPO with diesel (Frigo et al., 2014, Martínez et al., 2014; Aydın et al., 2015 \& Seljak et al., 2015) or biodiesel (Sharma et al., 2015 (a); Sharma et al., 2015(b)), increasing the intake temperature of air (McNeil et al., 2012), increasing compression ratio (Van de Beld et al., 2013),varying injection timing and pressure (Sudershan et al., 2018a), artificial neural network (ANN) modeling (Khandal et al., 2020).

An experimental study on CRDI engine run with diesel blend fuel (5\% ethanol-20\% biodiesel-75\% diesel) revealed that ethanol as an additive for the biodiesel-diesel blend does not need any modification of CI engine. A blend fuel 20\% bioethanol, 10\% rape seed methyl ester, and 70\% diesel used in Euro $5 \mathrm{CI}$ engine revealed reduction of smoke and NOx at all tested conditions and an increase of $\mathrm{CO}$ and $\mathrm{HC}$, especially at partial loads. Blend of $10 \%$ ethanol, $10 \%$ microalgae oil, and $80 \%$ diesel was found to be homogenous and stable without using a surfactant with improved properties of the resulted blend.

An experimental work reported that the best operating parameters for maximum BTE besides lowered emissions were injection timing of $10^{\circ} \mathrm{bTDC}$ and injection pressure of $900 \mathrm{bar}$ with fuel combinations of $70 \%$ plastic pyrolysis oil (PPO) with $28 \%$ diesel and 2\% ethanol (Sudarshan et al., 2018 b). Phase separation problem was encountered when percentage of ethanol was more than $15 \%$ in the blend (Gadwal et al., 2019). The presence of hydroxyl group in ethanol reduces particulate emissions of diesel engines. Blends of diesel-ethanol-fueled multicylinder diesel engine showed higher brake specific fuel consumption (BSFC) and improved brake thermal efficiency (BTE) for higher ethanol content in the blend. This work also revealed that carbon monoxide (CO) and smoke emission were reduced remarkably at higher loads (Armaset al., 2006 \& Tomicet al., 2013). The usage of ethanol with diesel in farm equipment engine resulted in lower smoke and particulate emissions (Kwanchareonet al., 2007). A study with blend of ethanol and diesel on diesel engine showed lower BTE, CO, hydrocarbon (HC), and smoke emissions with higher NOx emission (Sayin, 2010). Influence of blends of ethanol and biodiesel showed higher BTE with lower NOx and particulate matter (PM) emission in comparison with diesel fuel. BSFC, CO, and HC emissions increased with increase in the proportion of ethanol in the blends (Banapurmath et al., 2010).

\section{Motivation for the present study and objectives}

The detailed literature review revealed that TPO has been blended with diesel or biodiesel. There are some studies that used TPO-ethanol blend with diesel and biodiesel as pilot injection fuels (Lee et al., 2013 \& Lee et al., 2015). As scarce literature is available with blends of TPO-ethanol-diesel, an attempt is made to use blends of TPO, diesel, and ethanol as substitutes to neat diesel fuel to power diesel engine. The blends were prepared with different proportions of ethanol to study their effect on multicylinder engine performance, combustion, and tail pipe emissions. 
The experiments were conducted on multicylinder CRDI diesel engine for varied ethanol-diesel proportions at different speeds, and engine performance was compared with diesel fuel operation to make critical inferences.

\section{MATERIALS AND METHODS}

The crude tyre oil obtained from pyrolysis process contains impurities such as carbon particles, sulfur and moisture. The steps followed to reduce the sulfur and moisture content are as follows: treatment of hydrosulfuric acid, treatment with activated Bentonite and calcium oxide $(\mathrm{CaO})$, distillation by vacuum process, oxidative desulfurization, washing, and drying.

The first three steps reduce the impurities, and the last two steps reduce the sulfur content and moisture. $8 \%$ of sulfuric acid by weight was stirred well with $1000 \mathrm{ml}$ of crude oil for 4 hours and heated till temperature reaches $50^{\circ} \mathrm{C}$. The mixture was then allowed to settle the sludge for 40 hours. Two layers were formed after specified period with top layer as viscous oil and lower layer sludge. The clear viscous oil was treated with activated Bentonite and $\mathrm{CaO}$ by mixing with stirrer and it is maintaining at $70^{\circ} \mathrm{C}$ for 4 hours. After 24 hours, the whole content was filtered with cloth to obtain healed pyro oil. Distilled pyro oil was then heated in vacuum distillation. This distilled pyro oil was further treated with oxidative desulfurization process to reduce sulfur content. This was carried out using 100 gms of mixture containing 10 gms of $98 \%$ formic acid and $30 \%$ hydrogen peroxide mixed for 2 hours at $60^{\circ} \mathrm{C}$. This mixture was allowed to settle in one whole day. Clear pyrolysis oil got separated by separation funnel and further washed with distilled water. Finally, the clear pyrolysis oil was heated to a temperature of $110^{\circ} \mathrm{C}$ for about 30 minutes to remove moisture contents if any. The final product obtained was tyre pyrolysis oil (TPO). The flow chart of the entire process is shown in Figure 1.

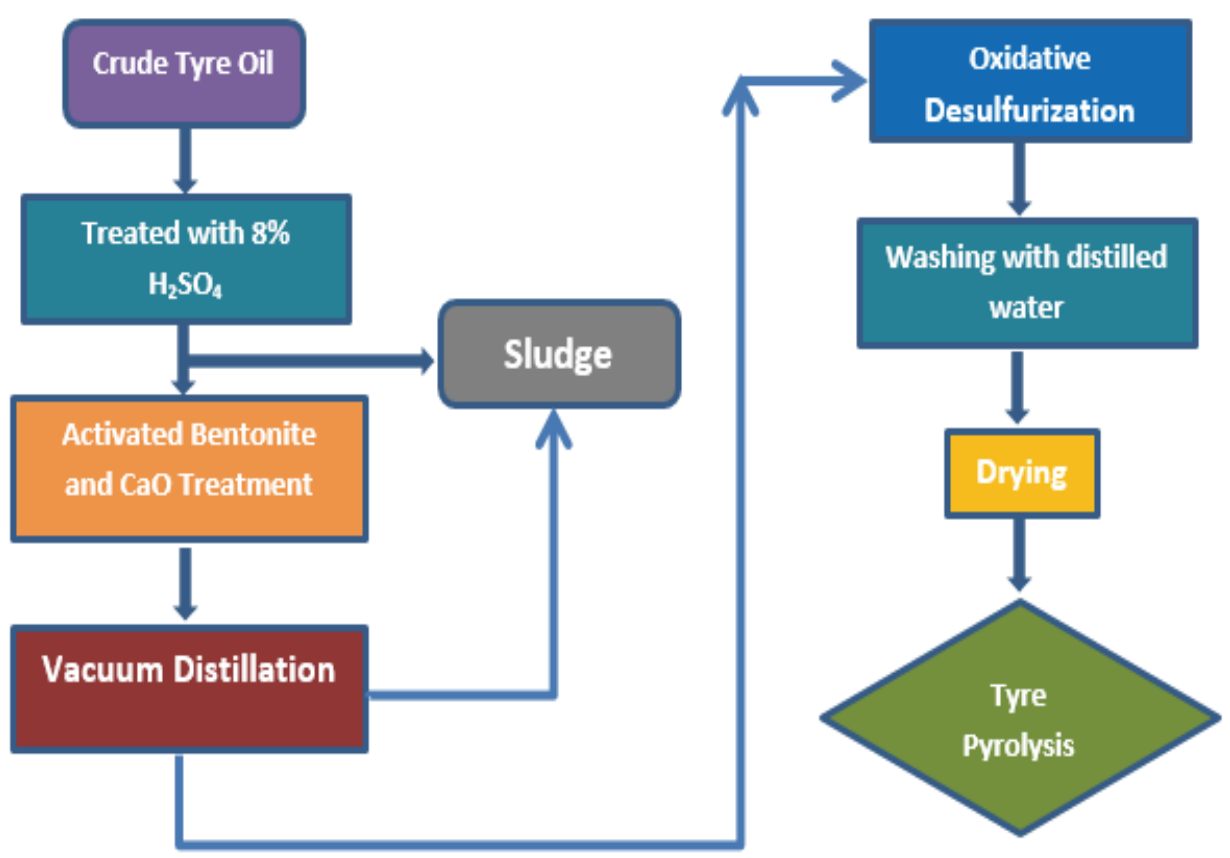

Figure 1. Flow diagram of TPO purification. 
Table 1. Properties of base fuels.

\begin{tabular}{|l|c|c|c|c|}
\hline \multicolumn{1}{|c|}{ Property } & Method & $\begin{array}{c}\text { Ethanol } \\
(\mathbf{E})\end{array}$ & $\begin{array}{c}\text { TPO } \\
\text { (T) }\end{array}$ & $\begin{array}{c}\text { Diesel } \\
\text { (D) }\end{array}$ \\
\hline Density $\left(\mathrm{kg} / \mathrm{m}^{3}\right)$ & ASTM D-4052 & 789 & 890 & 819 \\
\hline Kinematic viscosity $(\mathrm{cSt})$ & ASTM D-445 & 1.21 & 3.2 & 2.94 \\
\hline Flash point $\left({ }^{\circ} \mathrm{C}\right)$ & ASTM D-9390 & 14 & 48 & 57 \\
\hline Fire point $\left({ }^{\circ} \mathrm{C}\right)$ & ASTM D-9390 & 18 & 56 & 64 \\
\hline Calorific value $(\mathrm{kJ} / \mathrm{kg})$ & ASTM D-2015 & 26843 & 41430 & 44189 \\
\hline Cloud point $\left({ }^{\circ} \mathrm{C}\right)$ & ASTM D-4052 & -7 & 4 & 2 \\
\hline Pour point $\left({ }^{\circ} \mathrm{C}\right)$ & ASTM D-2500 & $\leq-35$ & $\leq-8$ & -16 \\
\hline Cetane number & ASTM D-613 & 8 & 47 & 52 \\
\hline Carbon residue $\%$ & ASTM D-524 & - & 0.02 & 0.35 \\
\hline
\end{tabular}

Table 2. Properties of Blends.

\begin{tabular}{|c|c|c|c|c|}
\hline Blends $\rightarrow$ & \multirow{2}{*}{ Method } & \multirow{2}{*}{$\begin{array}{c}\text { E: T: D } \\
\text { 02: } 60: 38\end{array}$} & \multirow{2}{*}{$\begin{array}{c}\text { E: T: D } \\
\text { 06: 60: } 34\end{array}$} & \multirow{2}{*}{$\begin{array}{c}\text { E: T: D } \\
\text { 12: } 60: 28\end{array}$} \\
\hline Property & & & & \\
\hline Density $\left(\mathrm{kg} / \mathrm{m}^{3}\right)$ & ASTM D-4052 & 848.4 & 839.3 & 832.2 \\
\hline Kinematic viscosity $(\mathrm{cSt})$ & ASTM D-445 & 3.0 & 2.98 & 2.96 \\
\hline Flash point $\left({ }^{\circ} \mathrm{C}\right)$ & ASTM D-9390 & 48 & 40 & 35 \\
\hline Fire point $\left({ }^{\circ} \mathrm{C}\right)$ & ASTM D-9390 & 55 & 47 & 41 \\
\hline Calorific value $(\mathrm{kJ} / \mathrm{kg})$ & ASTM D-2015 & 43122 & 41150 & 39582 \\
\hline Cloud point $\left({ }^{\circ} \mathrm{C}\right)$ & ASTM D-4052 & 3 & 2 & 2 \\
\hline Pour point $\left({ }^{\circ} \mathrm{C}\right)$ & ASTM D-2500 & -2 & -4 & -6 \\
\hline Cetane number & ASTM D-613 & 48.2 & 45.3 & 43.4 \\
\hline Carbon residue $\%$ & ASTM D-524 & 0.32 & 0.30 & 0.23 \\
\hline
\end{tabular}




\section{EXPERIMENTAL METHODOLOGY}

Figure 2 depicts multicylinder CRDI engine test rig. Tests on CRDI diesel engine were carried out at different engine speeds of $1200 \mathrm{rpm}, 1500 \mathrm{rpm}$, and $1800 \mathrm{rpm}$, and engine was operated from partial load to full load conditions. The blends were prepared with the combination of Ethanol-Pyrolysis oil-Diesel (E-T-D) in various proportions such as 02:60:38, 04:60:36, and 12:60:28, respectively, on volume basis. In blends, pyrolysis oil proportion was kept constant. For selected fuel combinations, experimentations were conducted in series for each combination. Six readings were recorded and averaged in order to analyze BTE and exhaust emissions such as CO, $\mathrm{HC}$, and NOx. The results were compared with standard diesel fuel results. To record various gases namely $\mathrm{HC}, \mathrm{CO}$, and NOx an AVL DiGas444G gas analyzer was used, which works on a nondispersive infrared technology (NDIR). To measure the concentration of oxygen and NOx gas, electrochemical (Fuel Cell) sensors were utilized. Smoke density of exhaust gas was measured by Smoke Meter AVL 437C.

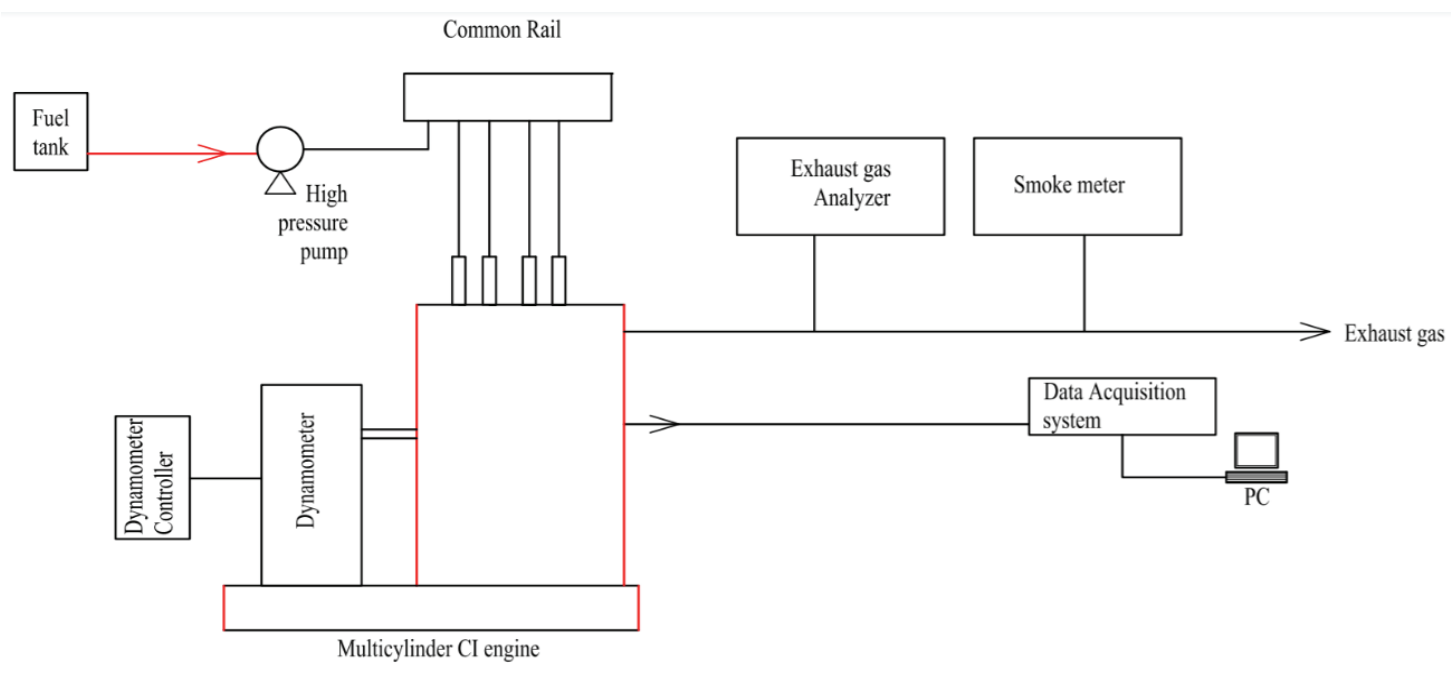

Figure 2. Schematic diagram of multicylinder CRDI experimental test rig.

Table 3. Specifications of CI Engine.

\begin{tabular}{|c|c|c|}
\hline Sl. No & Parameter & Specifications \\
\hline 1 & Make & Maruti Suzuki \\
\hline 2 & Engine type & 1.3 ltr CRDI Engine \\
\hline 3 & Static injection timing & $24^{\circ} \mathrm{bTDC}$ \\
\hline 4 & No. of cylinders & 4 \\
\hline 5 & No. of strokes & 4 \\
\hline 6 & Fuel & H. S. Diesel \\
\hline 7 & Rated power & 74 bhp@ $4000 \mathrm{rpm}$ \\
\hline 8 & Maximum torque and engine speed & 190 N-m@2000rpm \\
\hline 9 & Cylinder diameter & $0.0696 \mathrm{~m}$ \\
\hline 10 & Stroke length & $0.082 \mathrm{~m}$ \\
\hline 11 & Compression ratio & $17.5: 1$ \\
\hline
\end{tabular}


172 Performance and emission analysis of multicylinder common rail direct injection diesel engine powered with blends of tyre pyrolysis oil-ethanol diesel

Table 4. Specifications of Five gas Analyzer.

\begin{tabular}{|c|c|}
\hline Type & AVL DIGAS 444G \\
\hline Object of measurement & $\begin{array}{c}\text { Carbon Monoxide }(\mathrm{CO}) \\
\text { Oxides of Nitrogen }\left(\mathrm{NO}_{\mathrm{x}}\right) \\
\text { Hydrocarbon }(\mathrm{HC})\end{array}$ \\
\hline Range of measurement & $\begin{array}{c}\mathrm{HC}=0 \text { to } 20,000 \mathrm{ppm} \text { as vol } \\
\mathrm{CO}=0 \text { to } 10 \% \\
\mathrm{NO}_{\mathrm{X}}=0 \text { to } 5000 \mathrm{ppm} \text { vol }\end{array}$ \\
\hline Accuracy & $\begin{array}{c}\mathrm{HC}=+/-30 \mathrm{ppm} \mathrm{HC} \\
\mathrm{CO}=+/-0.03 \% \text { vol CO } \\
\mathrm{NO}_{\mathrm{X}}=+/-10 \% \text { ppm NO}\end{array}$ \\
\hline Resolution & $\begin{array}{c}\mathrm{HC}=1 \mathrm{ppm} \\
\mathrm{CO}=0.01 \% \mathrm{Vol} \\
\mathrm{NO}_{\mathrm{X}}=1 \mathrm{ppm}\end{array}$ \\
\hline Warm up time & $7 \mathrm{~min}$ \\
\hline Speed of Response Time & Within $15 \mathrm{sec}$. for $90 \%$ response \\
\hline Sampling & Directly sampled from tail pipe \\
\hline Power source & 100 to $240 \mathrm{~V} \mathrm{AC} \mathrm{/} 50 \mathrm{HZ}$ \\
\hline Weight & $\begin{array}{c}4.5 \mathrm{~kg} \text { net weight without } \\
\text { accessories }\end{array}$ \\
\hline Size & $270 \mathrm{~mm} \times 320 \mathrm{~mm} \times 85 \mathrm{~mm}$ \\
\hline
\end{tabular}

Table 5. Specifications of smoke meter.

\begin{tabular}{|c|c|}
\hline Type & AVL 437C \\
\hline Object of measurement & Smoke \\
\hline Measuring range opacity & $0-100 \%$ \\
\hline Accuracy & $+/-2 \%$ relative \\
\hline Resolution & $0.1 \%$ \\
\hline Smoke length & $0.430 \mathrm{~m}+/-0.005 \mathrm{~m}$ \\
\hline Ambient Temperature Range & $-5^{\circ} \mathrm{C}$ to $+45^{\circ} \mathrm{C}$ \\
\hline Warm up time & $10 \mathrm{~min}$ \\
\hline Speed of Response Time & Within 11 sec. for $90 \%$ response \\
\hline Sampling & Directly sampled from tail pipe \\
\hline Power supply & 100 to $240 \mathrm{~V}$ AC $/ 50 \mathrm{HZ}$ \\
\hline
\end{tabular}




\section{UNCERTAINTY ANALYSIS}

A study revealed the performance of a novel control strategy for imperfect systems. This strategy takes care of unavoidable imperfections associated with physical systems accounting the hidden dynamics associated with them to improve overall system performance (Bucolo et al., 2019). The uncertainties for the current investigation are given in the Table 6. Average of six readings was taken to overcome the measurement errors and for further result analysis.

Table 6. Uncertainties for the present study.

\begin{tabular}{|c|c|}
\hline Measured variable & Accuracy ( \pm ) \\
\hline Load (N) & 0.1 \\
\hline Engine speed (rpm) & 1 \\
\hline Temperature, $\left({ }^{\circ} \mathrm{C}\right)$ & 1 \\
\hline Fuel consumption $(\mathrm{g})$ & 0.1 \\
\hline Measured variable & Uncertainty (\%) \\
\hline HC & \pm 1.4 \\
\hline Calculated parameters & \pm 1.4 \\
\hline NOx & \pm 2.7 \\
\hline
\end{tabular}




\section{RESULTS AND DISCUSSIONS}

The performance, emission, and combustion characteristics of multicylinder CRDI engine powered with blends of TPO, diesel, and ethanol are discussed in this section. The test matrix is provided in Table 7.

Table 7. Test Matrix.

\begin{tabular}{|c|c|c|}
\hline Phase & Operating condition & Speed \\
\hline Diesel Operation & $\begin{array}{c}\mathrm{CR}=17.5, \mathrm{IP}=900 \text { bar, IT }=10^{\circ} \mathrm{BTDC} \\
\text { Fuel: Diesel }\end{array}$ & $1500 \mathrm{RPM}$ \\
\hline First Phase & $\begin{array}{c}\mathrm{CR}=17.5, \mathrm{IP}=900 \text { bar, } \mathrm{IT}=10^{\circ} \mathrm{BTDC} \\
\text { Fuel blend: } \mathrm{E}-\mathrm{T}-\mathrm{D}=02: 60: 38\end{array}$ & $1200,1500,1800 \mathrm{RPM}$ \\
\hline Second Phase & $\begin{array}{c}\mathrm{CR}=17.5, \mathrm{IP}=900 \text { bar, } \mathrm{IT}=10^{\circ} \mathrm{BTDC} \\
\text { Fuel blend: } \mathrm{E}-\mathrm{T}-\mathrm{D}=02: 60: 38\end{array}$ & $1200,1500,1800 \mathrm{RPM}$ \\
\hline Third Phase & $\begin{array}{c}\mathrm{CR}=17.5, \mathrm{IP}=900 \text { bar, IT }=10^{\circ} \mathrm{BTDC} \\
\text { Fuel blend: } \mathrm{E}-\mathrm{T}-\mathrm{D}=02: 60: 38\end{array}$ & $1200,1500,1800 \mathrm{RPM}$ \\
\hline
\end{tabular}

\section{Influence of engine speed and fuel blends on brake thermal efficiency}

Figure 3 shows the effect of engine speeds and selected blends on BTE of CRDI engine at different loads. For all fuel blends, BTE was lower as compared to diesel. This may be due to the blends having lower energy contents and higher viscosity (Montajir et al., 2000; Sudarshan, 2018b; Sayin, 2010\& Manjunath et al., 2019). When concentration of ethanol was increased, marginal decrease in BTE was observed. Lower cetane number of ethanol could be another factor for low BTE (Gadwal, 2019). With increase in load and speed, BTE was increased for all combinations of fuel blends. For the selected combination, E02:T60: D38 showed better BTE as compared to other combinations. Among all speeds, $1800 \mathrm{rpm}$ showed better results for all combinations of fuel blends (An et al., 2012). Knocking was observed when engine speed increased beyond $1800 \mathrm{rpm}$. Similar results were observed in literature (Sjoberg et al., 2005).

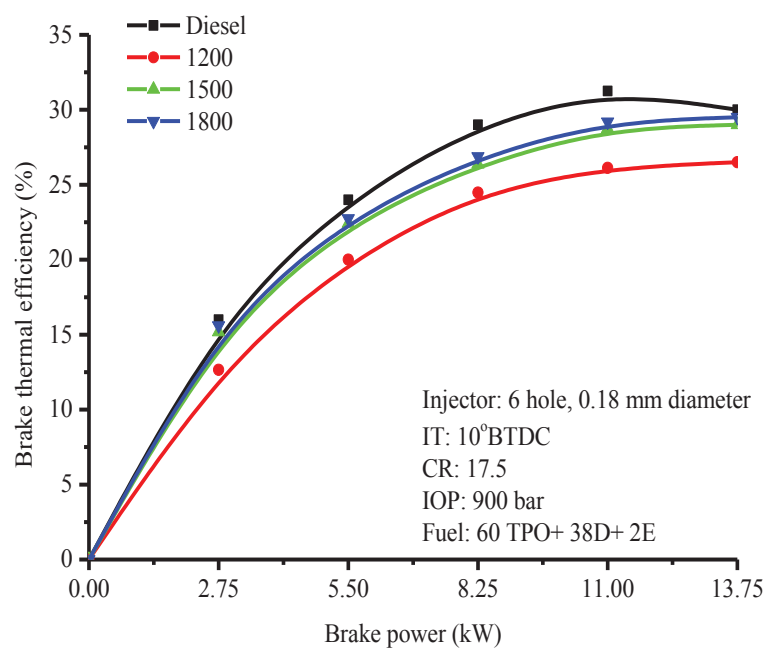



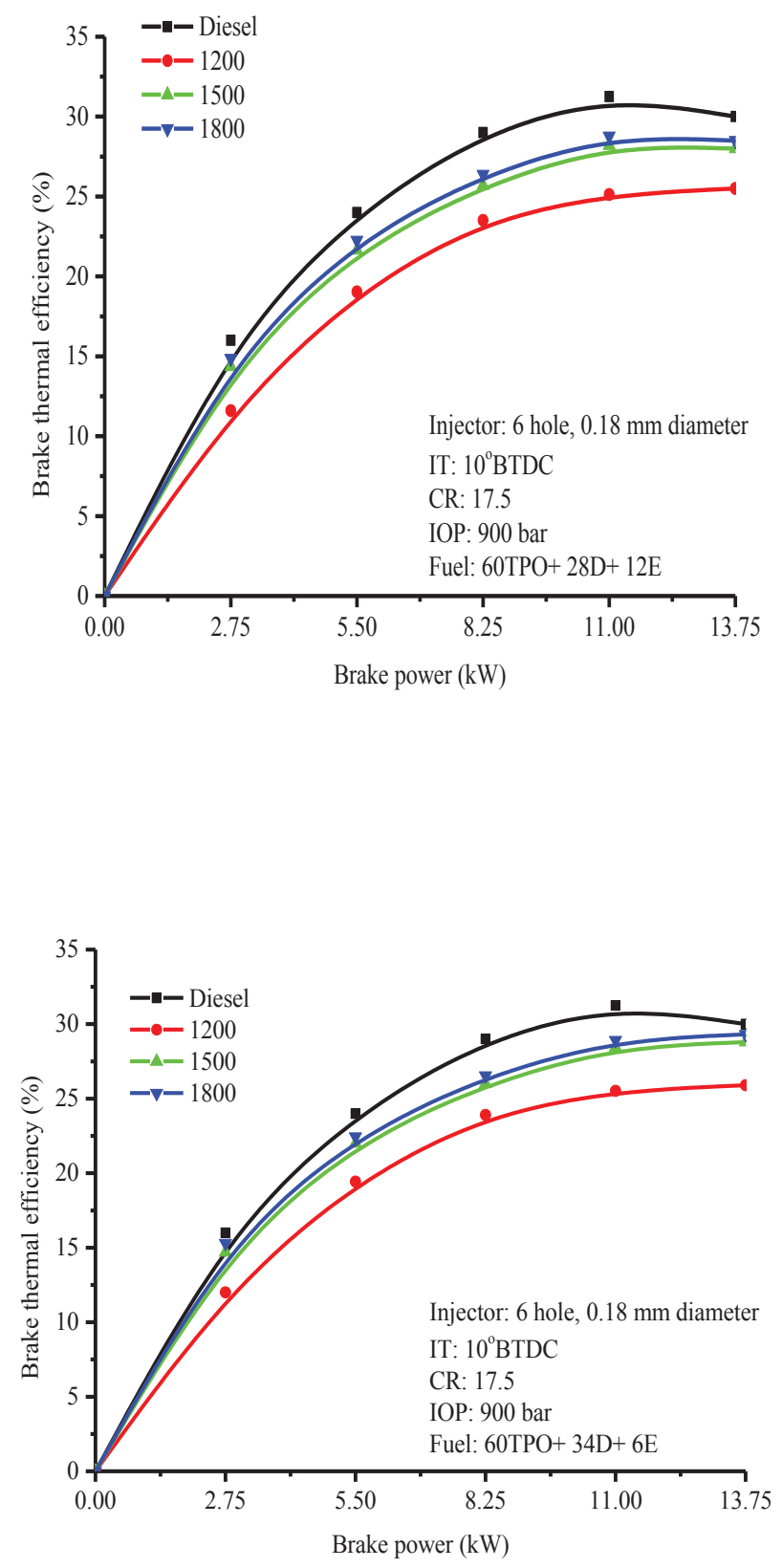

Figure 3. Effects of speed on BTE for different fuel blends at different loads.

\section{Emissions}

In this section, exhaust emissions from the engine are discussed for the different fuel blends used. 


\section{HC Emissions}

Figure 4 represents the $\mathrm{HC}$ emissions of CRDI engine at varied engine speeds and loads using selected fuel blends. $\mathrm{HC}$ emissions were higher than the diesel for all fuel blends and speeds. It was observed that HC increases with increase in load. Increase in proportion of ethanol increased emissions of HC. Slow evaporation of ethanol blends due to high heat of vaporization results in poor mixing of air-fuel mixture. This leads to increase in spray dispersion, which causes undesirable fuel impingement on the walls of combustion chamber contributing to increased $\mathrm{HC}$ emission. Further higher viscosity and lower cetane number could be another reason for increased HC emissions (Indudhar et al., 2019; Sudarshan, 2018b; Sayin, 2010; \& Gadwal, 2019). For higher engine speed, HC emission was lower for all combinations of fuels. This can be attributed to enhanced mixing of air and fuel mixtures at higher speeds (John, 1988).
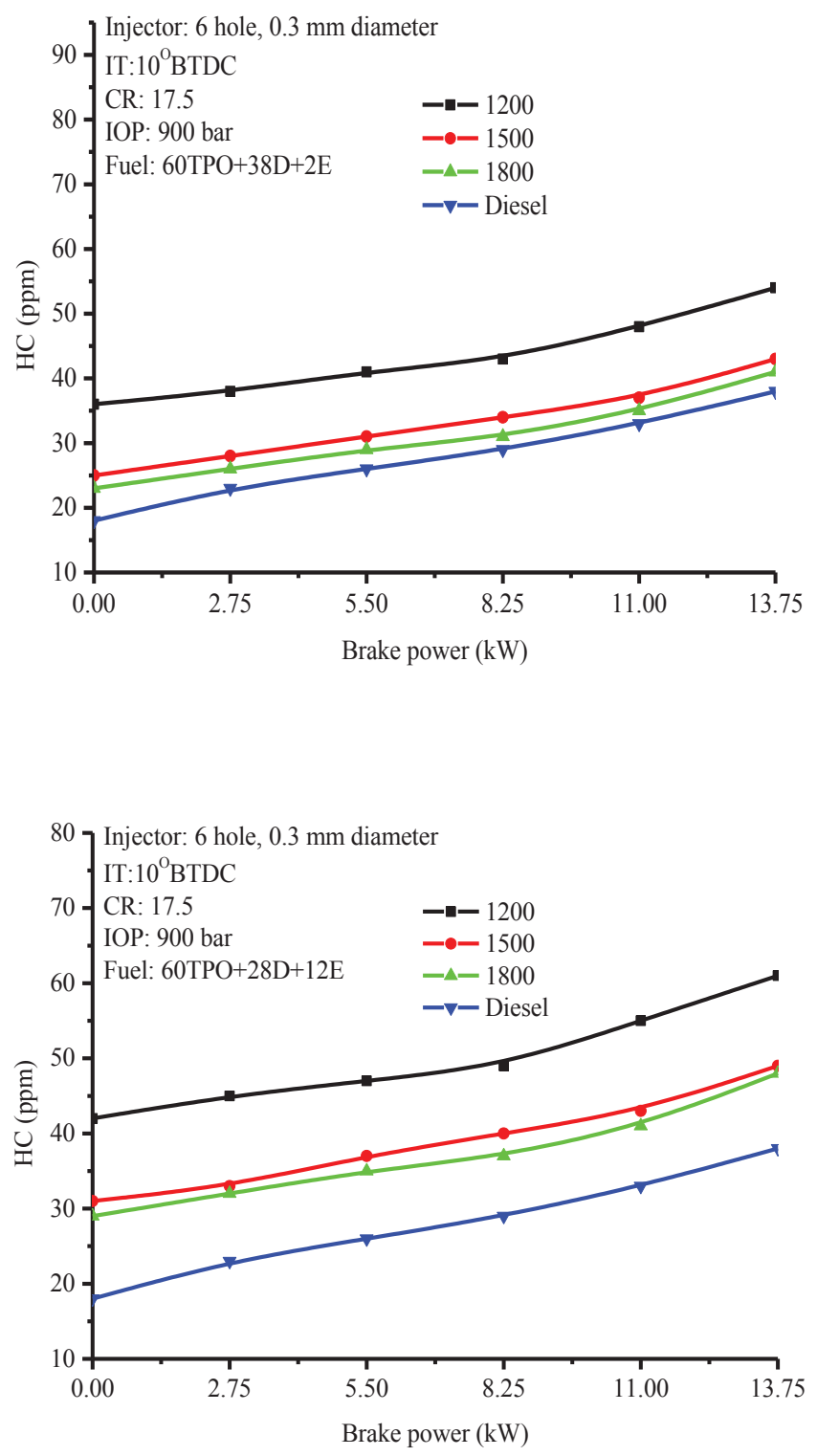


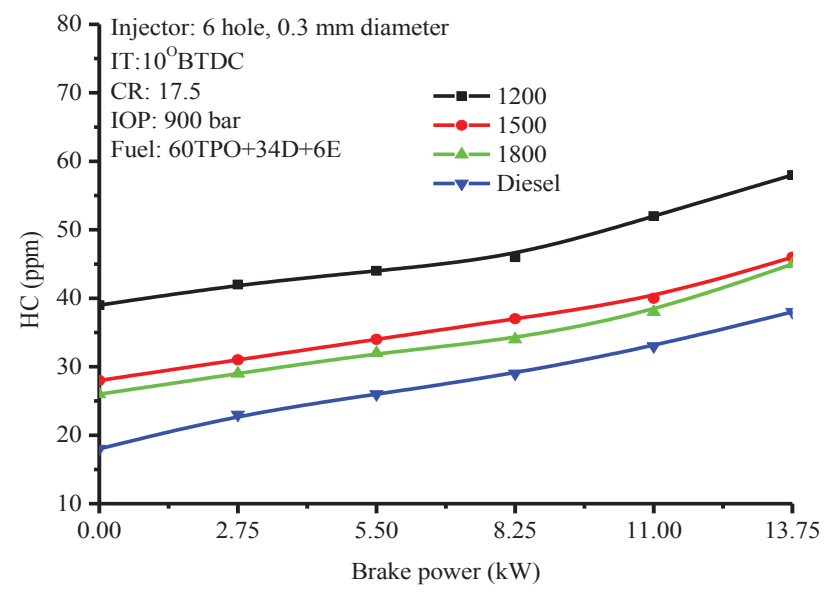

Figure 4. Effect of speed on HC emission of fuel blends at different loads.

\section{CO Emissions}

Figure 5 depicts the influence of engine speed and selected fuel blends on $\mathrm{CO}$ emissions at various engine loads. $\mathrm{CO}$ emissions of the blends were higher as compared to diesel, with an increase in load CO emissions increased. This may be due to high concentration of blends, which leads to inadequate combustion associated with smaller combustion periods when engine speed is high. Due to lower cetane number of the combinations of fuels, ignition delay (ID) increased, which is shown in Figure 8, resulting in the accumulation volume of fuel before the commencement of combustion. The $\mathrm{CO}$ emissions were increased with increase in ethanol proportion in the blends. The higher viscosity of blends causes the spray characteristics degraded, which results in improper mixture formation. Lower combustion temperature could also be the reason. Hence, poor combustion of selected combinations causes formation of more CO emissions. Similar results could be seen in literature (Sudarshan, 2018b; Gadwal, 2019; Sayin, 2010 \& Jaichandar et al., 2013). This may be due to incomplete combustion of the blended fuels, which are having low cetane number with longer ID; moreover, the quantity of fuel burnt was more in expansion stroke due to more combustion duration at lower speed as shown in Figure 9. Further injected volume of blends was more due to low heating value, which leads to improper mixture formation.

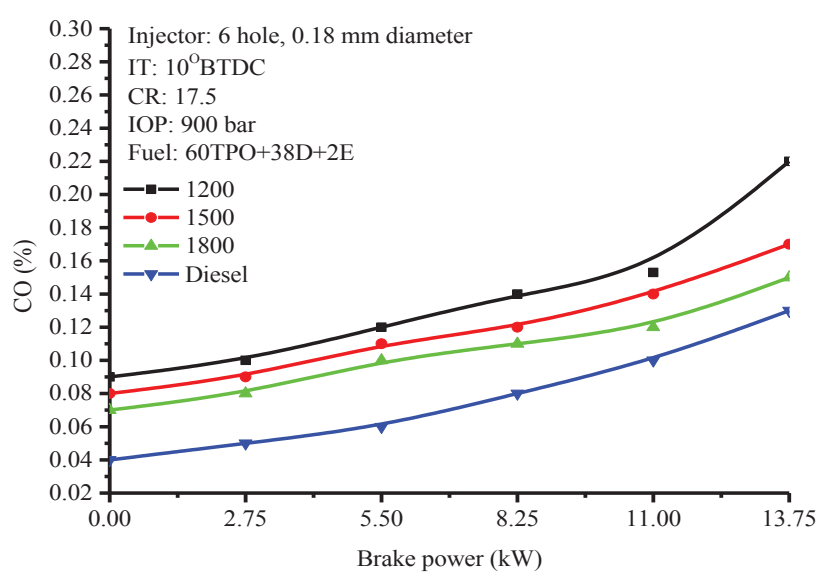



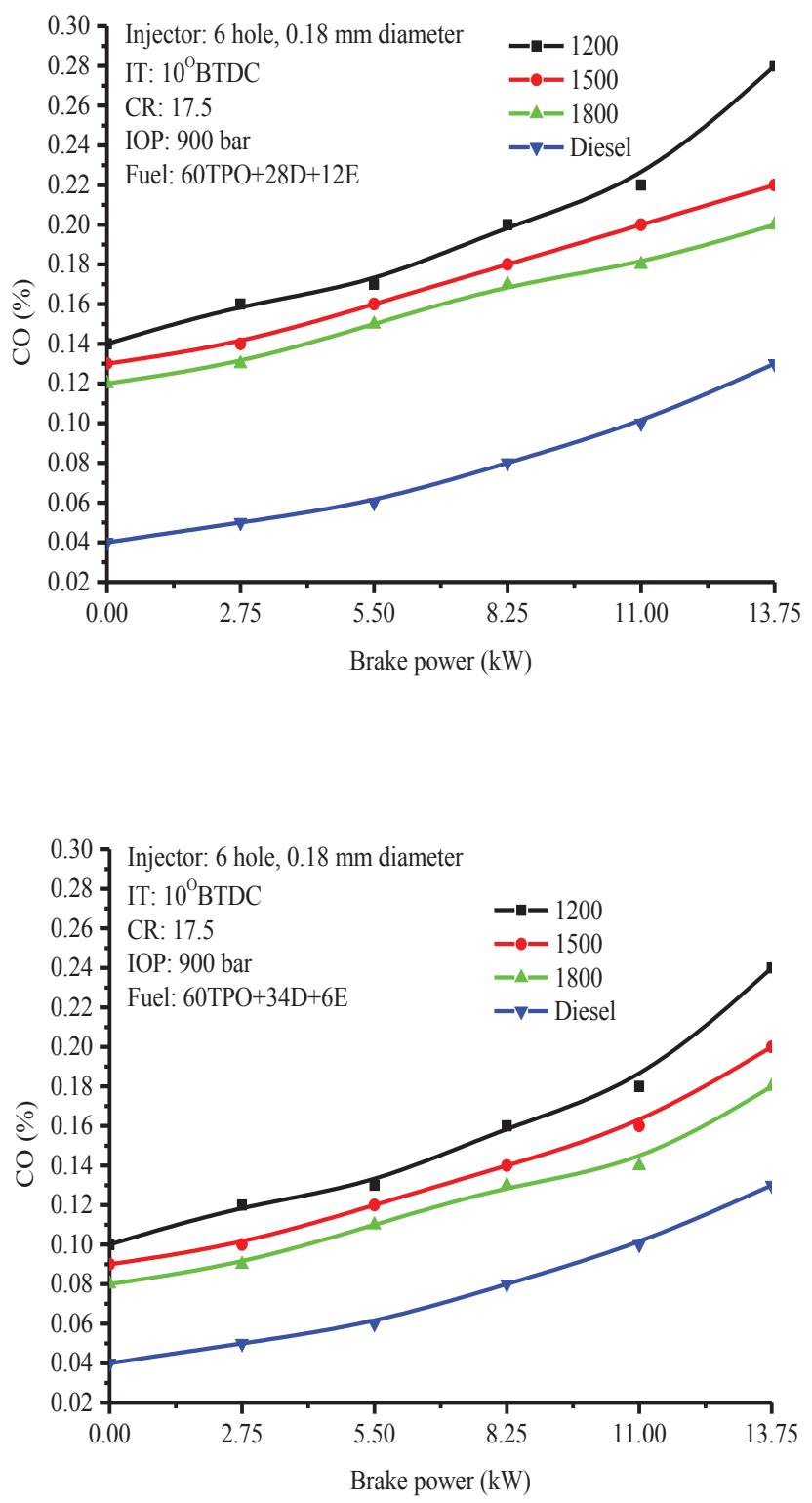

Figure 5. Effect of speed on Carbon monoxide emission of fuel blends at different loads.

\section{NOx Emissions}

Figure 6 represents the emissions of NOx of multicylinder CRDI diesel engine powered with blends of TPO with diesel and ethanol at different engine speeds and loads. NOx emissions for all blends were low compared to diesel. The rate of formation of NOx mainly depends on flame temperature, residence time, and availability of oxygen in combustion chamber. 
At high engine load, more quantity of fuel was inducted resulting in high temperature of gas and in turn more formation of NOx. Compared to diesel, the peak in-cylinder temperature was lower for selected combinations of fuels. With increase in the proportion of ethanol in the blend, combustion temperature was lesser. This is due to poor vaporization rate of blended fuels and the high latent heat of evaporation of ethanol in the blends. Lower peak pressure (PP) and heat release rate (HRR) shown in figure 10 and figure 11, respectively, at higher ethanol proportion could also be the reason for lower combustion temperature. Hence, NOx emissions for the blends were lower as compared to diesel for all speeds. This trend could also be attributed to higher water and oxygen contents in TPO-diesel-ethanol blends. Similar results were reported in literature (Sudarshan, 2018b; Gadwal, 2019; Sayin, 2010 \&Lee et al., 2013).
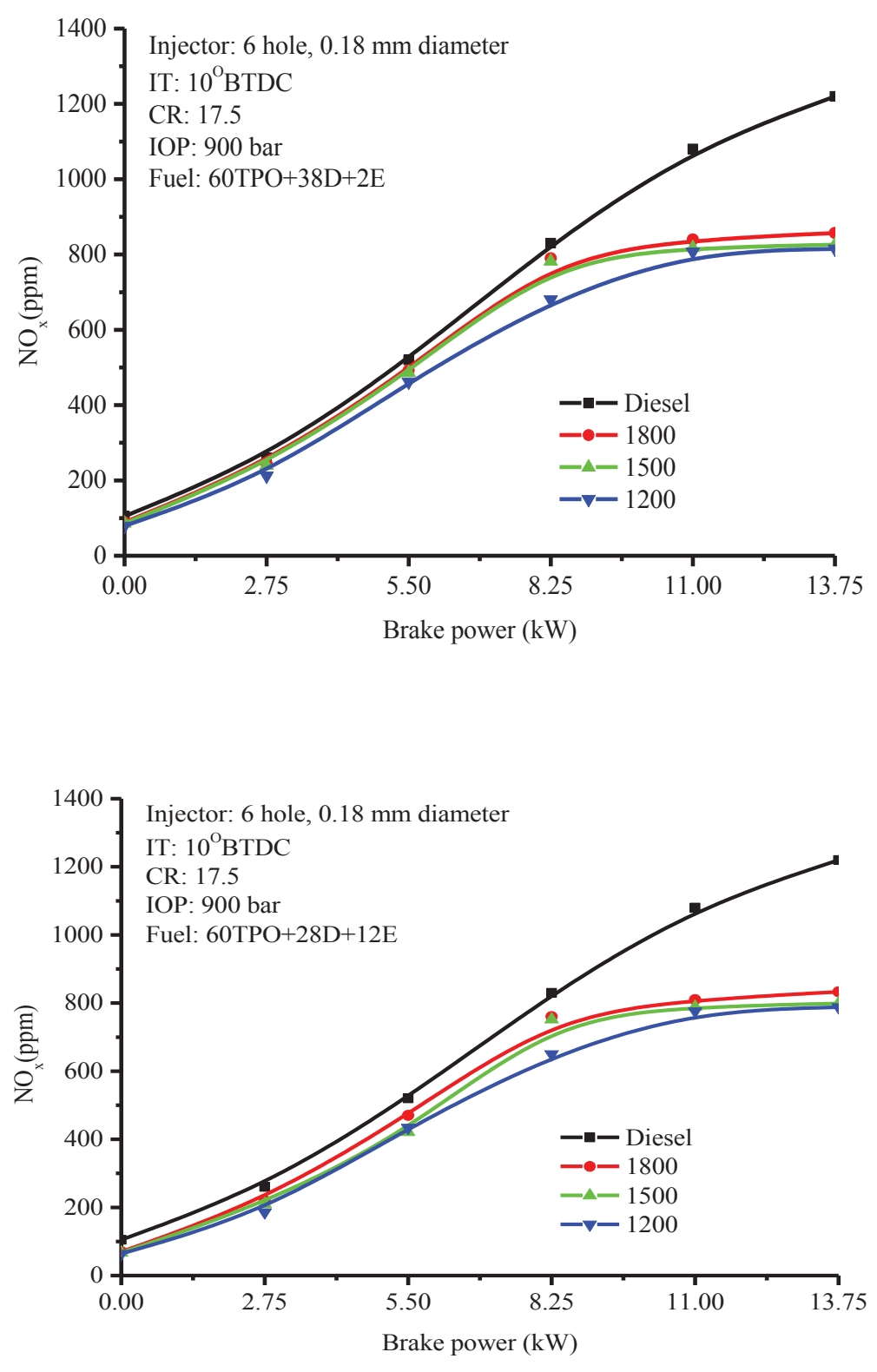


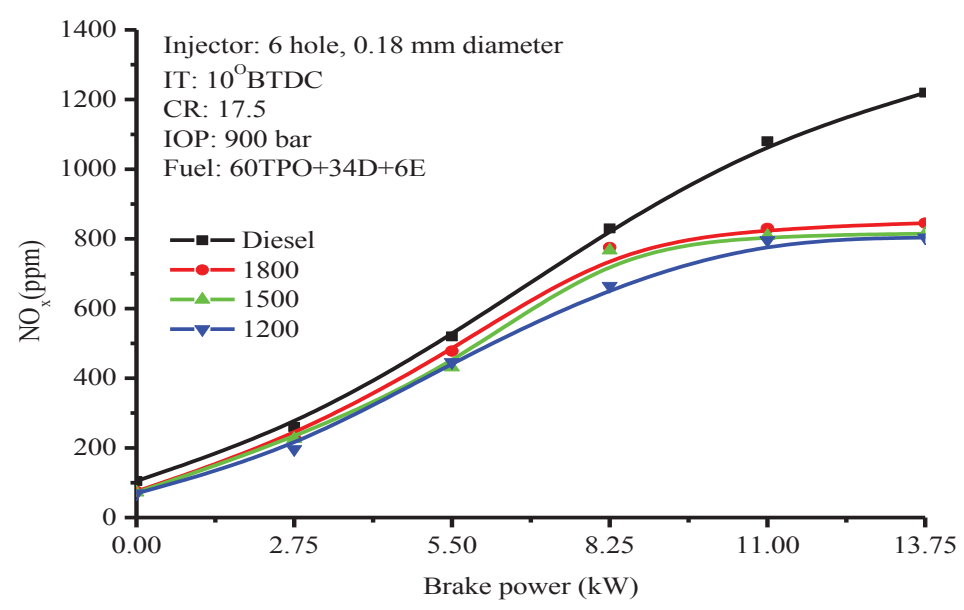

Figure 6. Effect of speed on oxides of nitrogen emission of fuel blends at different loads.

\section{Smoke emissions}

Figure 7 shows the influence of engine speed and load on smoke emissions of CRDI engine for the fuel blends. Increased smoke opacity was observed with increased loading operation for all the fuel blends for the three speeds of engine operation. Smoke formation is spontaneous at higher loads (Soudagar et al., 2019). Increased quantity of fuel injected during higher engine loads decreased air-fuel ratio that leads to higher smoke emissions. Smoke emissions were high when engine was operated with blends as compared to diesel. This is due to poor vaporization rate of blended fuels and the high latent heat of evaporation of ethanol in the blends. Smoke emissions decreased with increased speed, which may be attributed to earlier injection that leads to higher in-cylinder temperatures, facilitating more time for oxidation of the soot particles before opening of exhaust valve. Inbuilt fuel oxygen and improved mixing at higher speeds reduce the smoke formation. Similar results could be seen in literature (Sudarshan, 2018b; Gadwal, 2019; Banapurmath et al., 2008; Hulwan et al., 2011).

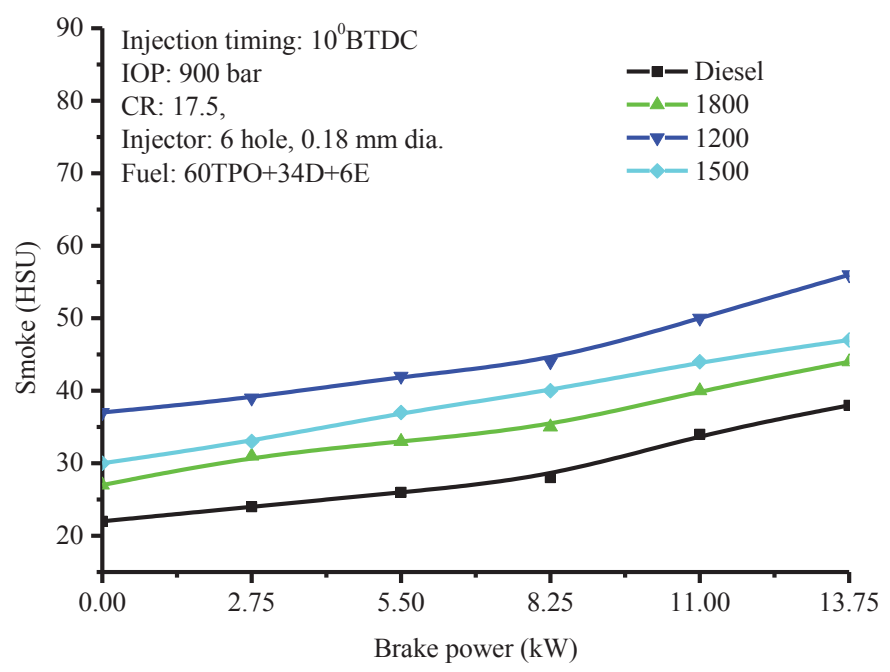



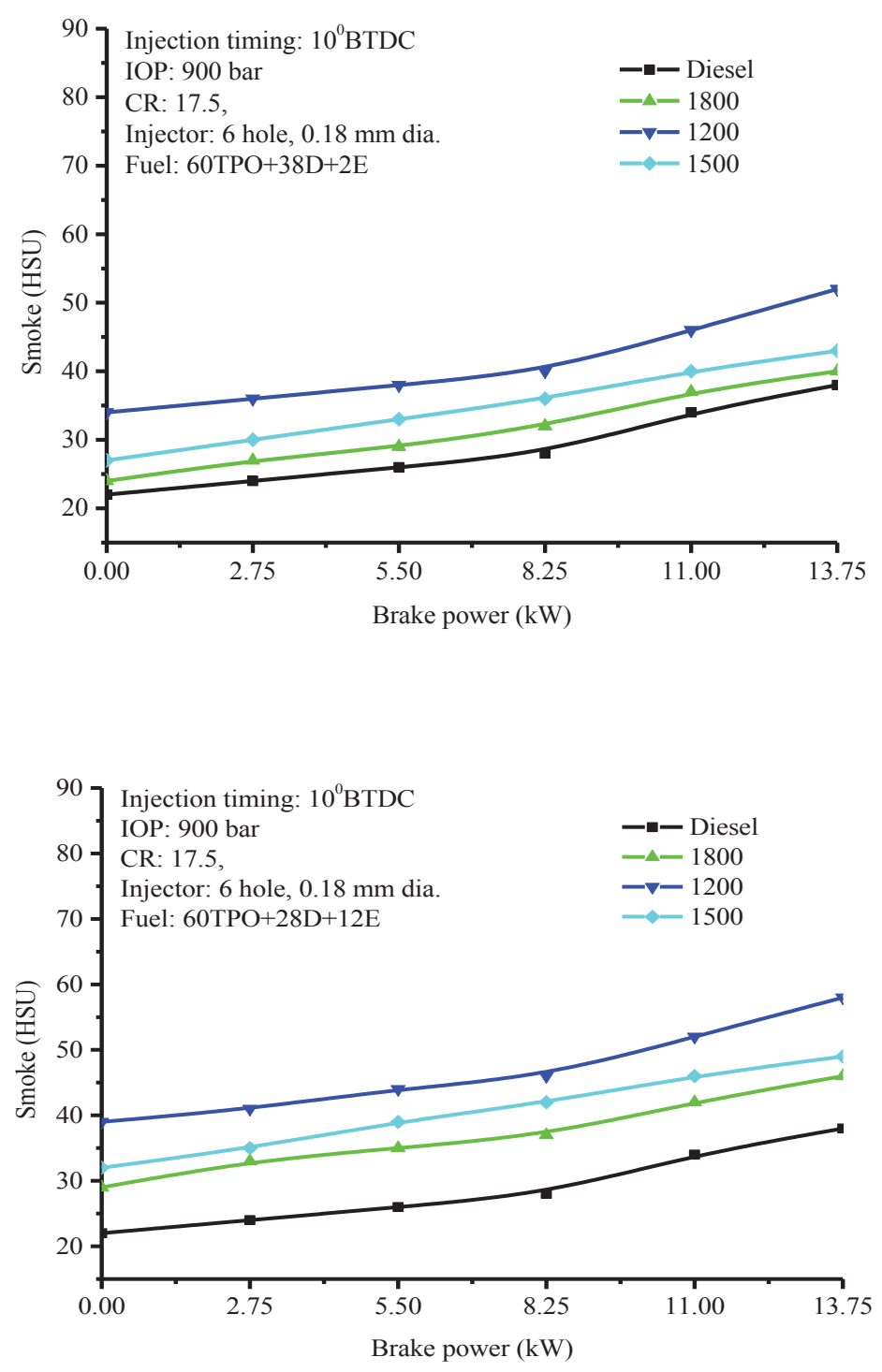

Figure 7. Effect of speed on smoke emission of fuel blends at different loads.

\section{Combustion characteristics}

In this section, combustion characteristics of the engine are discussed for the different fuel blends used.

\section{Ignition delay (ID)}

Figure 8 depicts the effect of engine speed and load on ignition delay of CRDI engine for the fuel blends. ID calculated based on the static IT. Decreasing trend of ID was found with increased BP. Temperature of combustion gases gets elevated at higher BP; thereby, the decreasing trend of ID was reported with all speeds, and, at the same 
time, lower ID was observed with higher speed. ID was high when engine was operated with blends in comparison to diesel. This is due to poor vaporization rate of blended fuels and the high latent heat of evaporation of ethanol in the blends. Decrease in cetane number and density could also be responsible for increase in ID at higher proportion of ethanol (Subbaiah, G.V. et. al., 2010; Clenci, A. et al., 2016). Also, higher self-ignition temperature of ethanol blends is responsible for the increase in ID. Similar results could be seen in literature (Banapurmath et al., 2008; Hulwan et al., 2011).
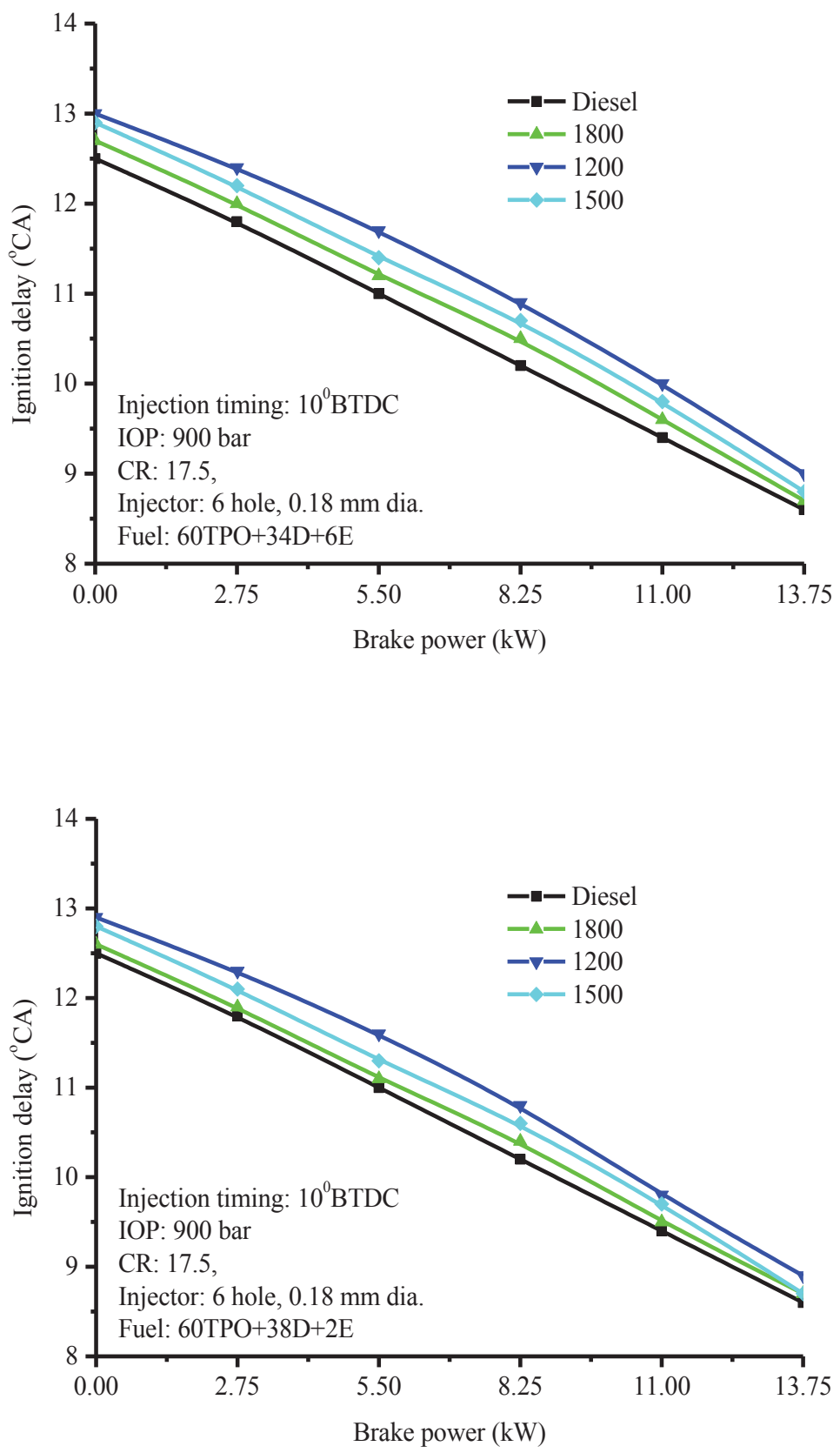


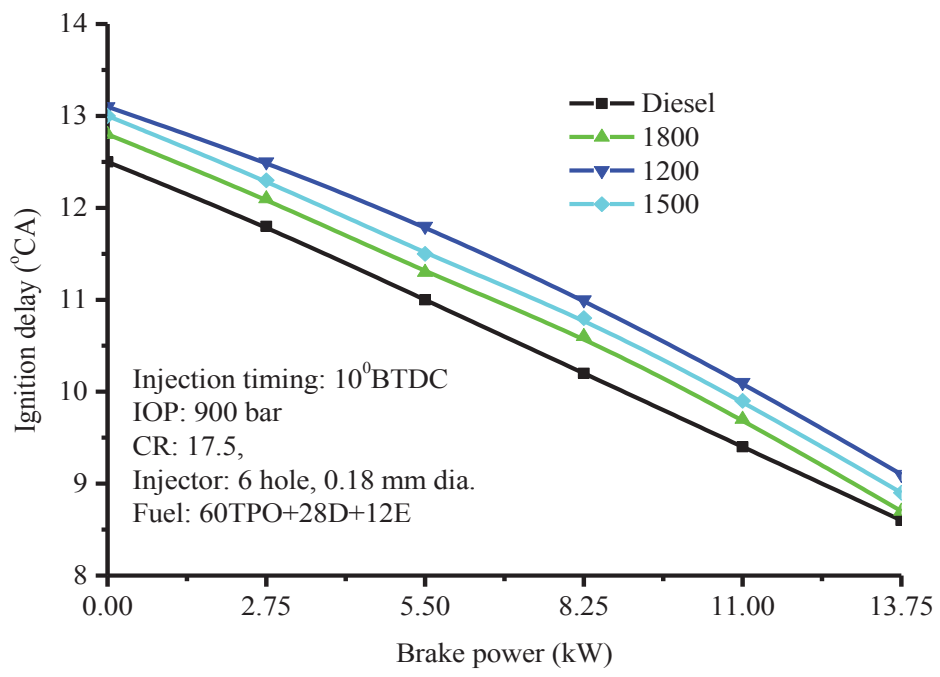

Figure 8. Effect of speed on ignition delay of fuel blends at different loads.

\section{Combustion duration (CD)}

The variation in $\mathrm{CD}$ is provided in Figure 9, and $\mathrm{CD}$ was calculated with time duration between start of combustion (SOC) and 90\% cumulative heat release. CD increased with higher BP for all speeds. Higher CD was observed for blends as compared to diesel, and higher proportion of ethanol in blends also showed higher CD. It might be because of higher viscosity that led to inhomogeneity in air-fuel mixing, lower gas temperature, and pressure. Also, due to delayed combustion after top dead center (aTDC). However, CD was reduced with speed due to better combustion as compared to lower speed. Similar results were reported in literature (Hulwan et al., 2011).

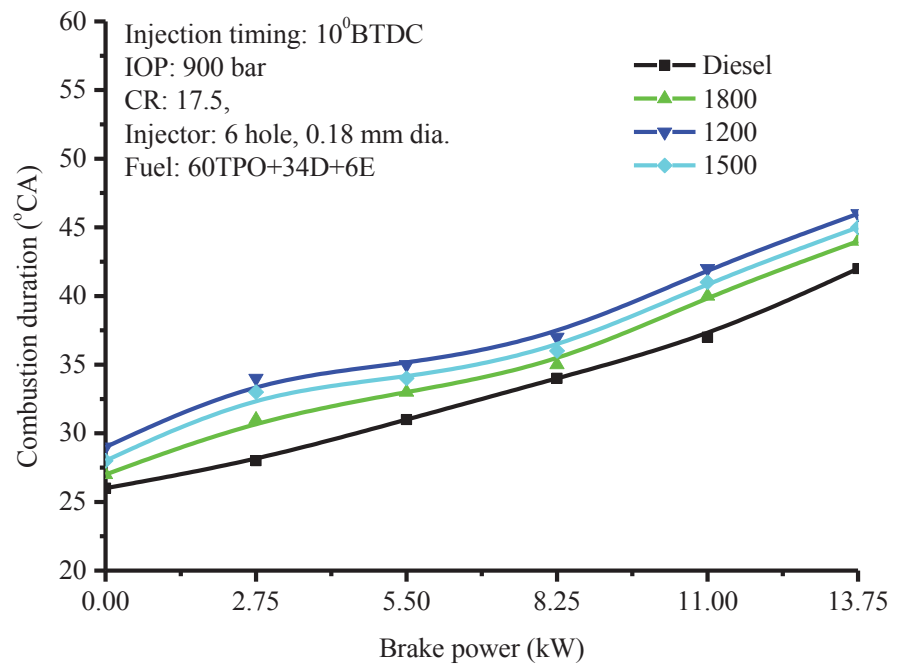


184 Performance and emission analysis of multicylinder common rail direct injection diesel engine powered with blends of tyre pyrolysis oil-ethanol diesel
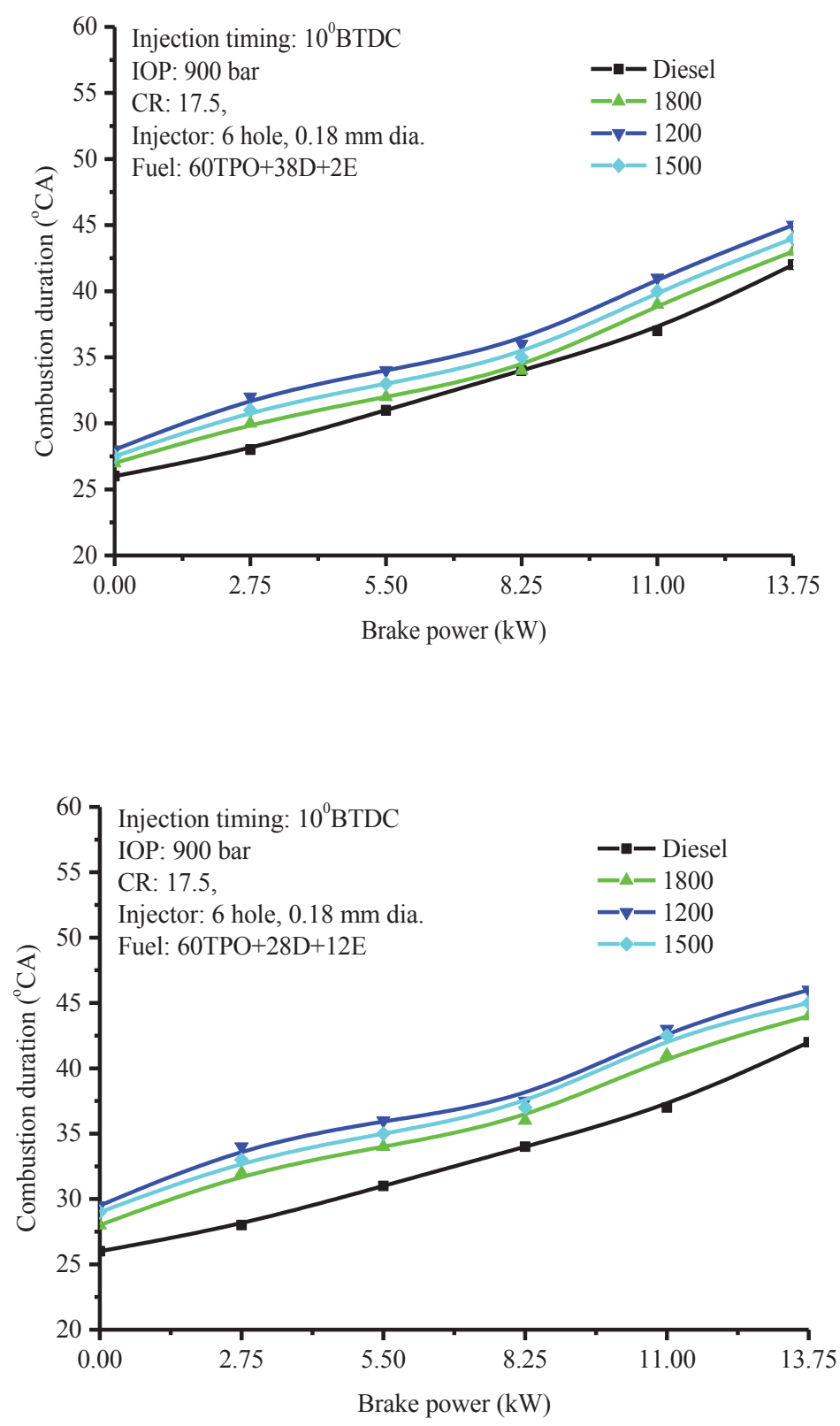

Figure 9. Effect of speed on combustion duration of fuel blends at different loads.

\section{Peak Pressure (PP) and Heat Release Rate (HRR)}

Figure 10 illustrates the effect of speed and load on peak pressure. The PP depends on the combustion speed and total amount of fuel burnt in rapid combustion phase period. Higher PP was found with higher BP. At all speed, slower burning nature of blends during ID period could be responsible for lower PP. It could be because of combined 
impact of slightly longer ID and slightly higher adiabatic flame temperature. Figure 11 shows variation in HRR with $\mathrm{BP}$ of the engine powered with blends used. All blends showed increasing trend of HRR with BP because of more fuel injected. Better air fuel mixture, better combustion, higher cylinder gas temperature, and pressure prevailed might be the reason for the higher HRR at higher speed. Blends showed lower HRR as compared to diesel due to poor combustion qualities. For higher ethanol proportion in blends, rapid premixed combustion and improved diffusive combustion were observed at high loads. Similar results were reported in literature (Hulwan et al., 2011, Tutak W et.al., 2016).

HRR was determined with in-cylinder gas pressure data. HRR at each CA was calculated using equation 1.

$$
Q_{a p p}=\left(\frac{\gamma}{\gamma-1}\right) p \cdot d v+\left(\frac{1}{\gamma-1}\right) v \cdot d p+Q_{\text {wall }}
$$

where

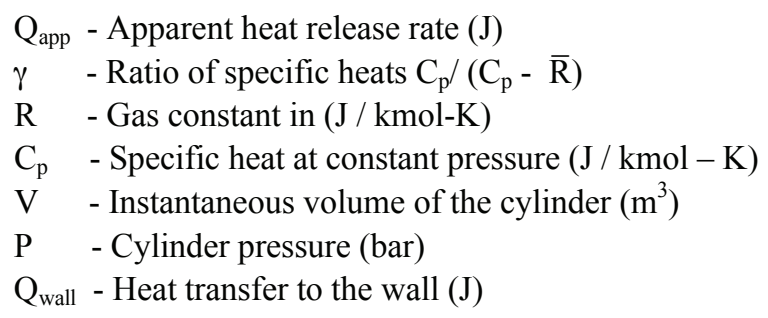

For this calculation, cylinder gas was assumed to behave as an ideal gas (air) with specific heats being dependent on temperature (Hayes et al., 1986). The specific heat was found using the equation 2.

$$
C p=\left[3.6359-\frac{1.33736 T}{1000}+\frac{3.29421 T^{2}}{1 \times 10^{6}}-\frac{-1.91142 T^{3}}{1 \times 10^{9}}+\frac{0.275462 T^{4}}{1 \times 10^{12}}\right] R
$$

for $\mathrm{T}<1000 \mathrm{~K}$

$$
C p=\left[3.04473+\frac{1.338056 T}{1000}-\frac{0.488256 T^{2}}{1 \times 10^{6}}+\frac{0.0855475 T^{3}}{1 \times 10^{9}} \cdot-\frac{0.00570127 T^{4}}{1 \times 10^{12}}\right] R
$$

for $\mathrm{T}>1000 \mathrm{~K}$

Heat transferred to the wall was determined with the Hohenberg equation (4) (Hohenberg, 1979) and assuming the wall temperature to be 723 (Hayes et al., 1986).

$$
Q_{\text {wall }}=h \times A \times[T g-T w]
$$

where $h=C 1 V^{-0.06} P^{0.8} T^{-0.4}\left(V_{P}+C_{2}\right)^{0.8}$

h - Heat transfer coefficient in $\mathrm{W} / \mathrm{m}^{2} \mathrm{~K}$ 
$\mathrm{C}_{1} \& \mathrm{C}_{2}-\quad$ Constants, $130 \& 1.4$

$\mathrm{V}-$ - Cylinder volume in $\mathrm{m}^{3}$

$\mathrm{P} \quad-\quad$ Cylinder pressure in bar

$\mathrm{T} \quad-\quad$ Cylinder gas temperature in $\mathrm{K}$

$\mathrm{V}_{\mathrm{P}} \quad-\quad$ Piston mean speed in $\mathrm{m} / \mathrm{s}$

A - Instantaneous Area $\left(\mathrm{m}^{2}\right)$
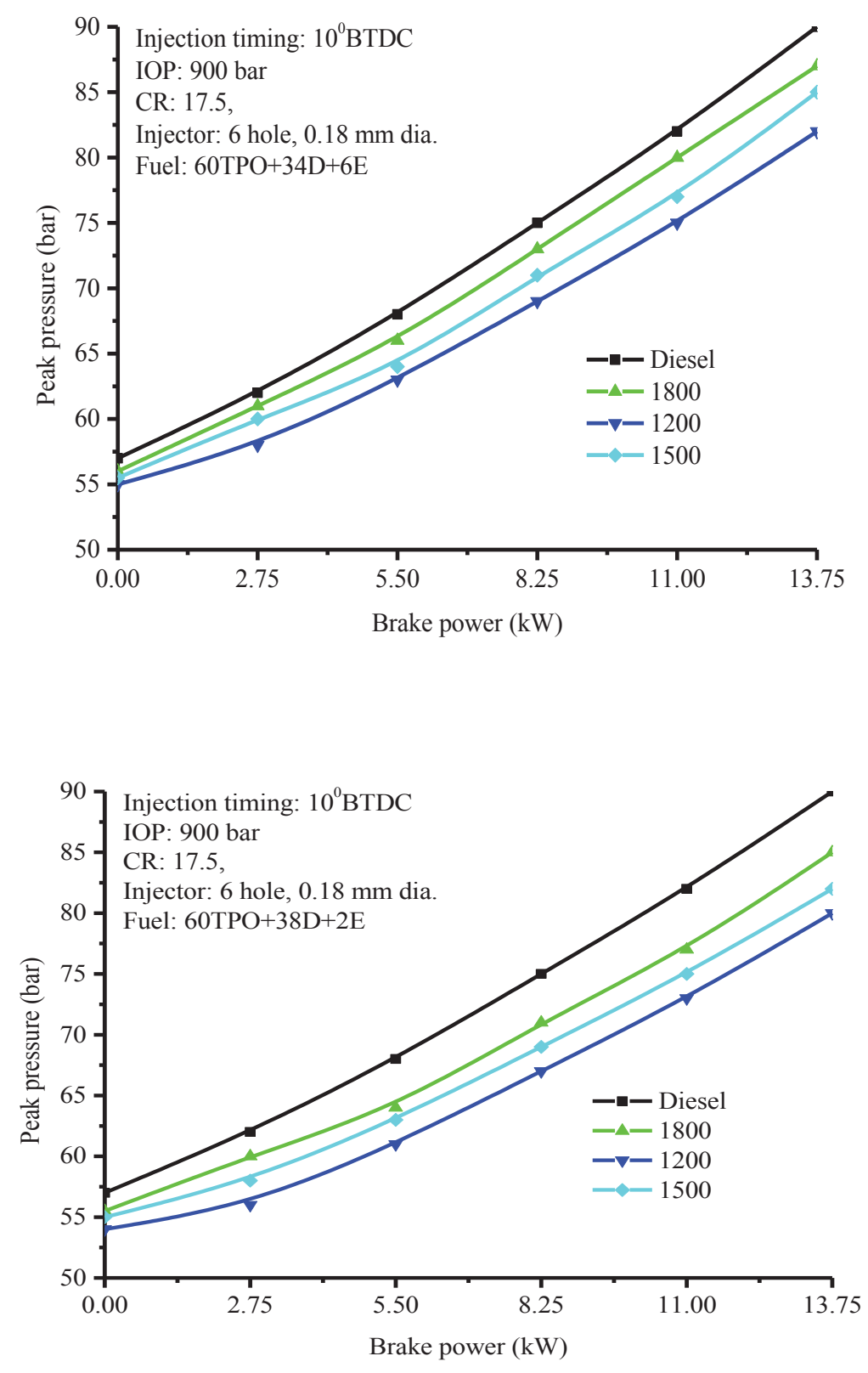


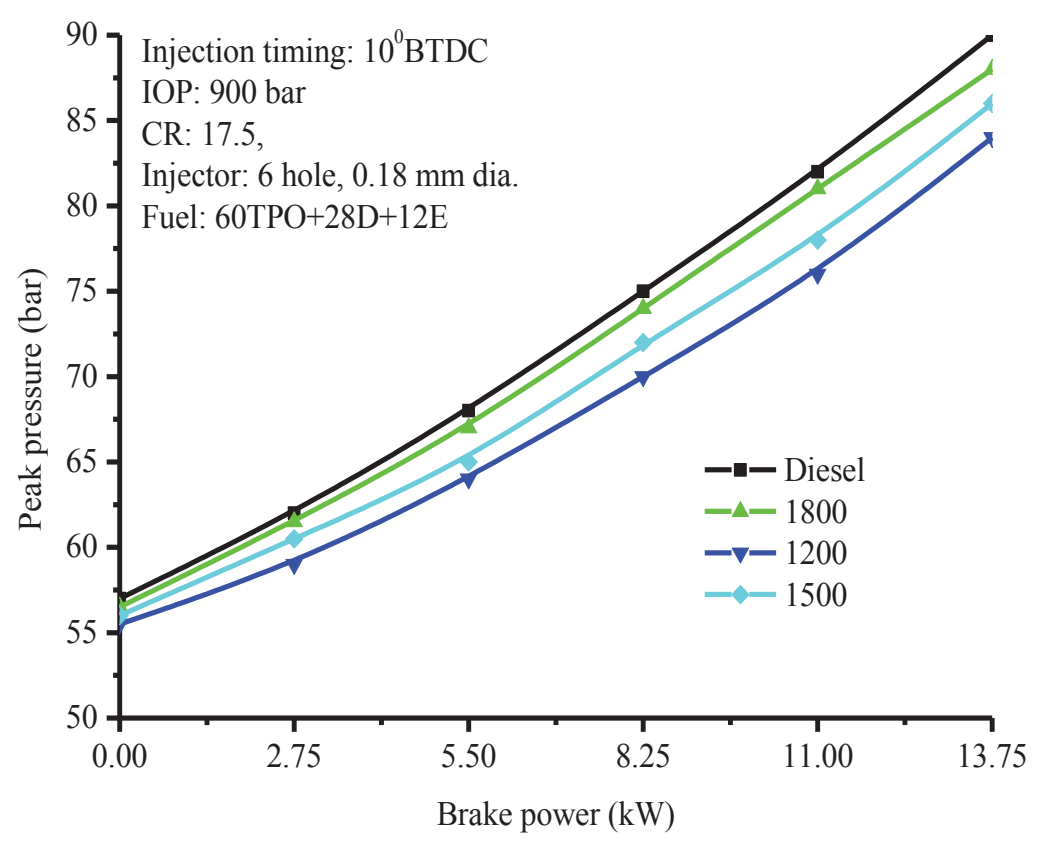

Figure 10. Effect of speed on peak pressure of fuel blends at different loads.

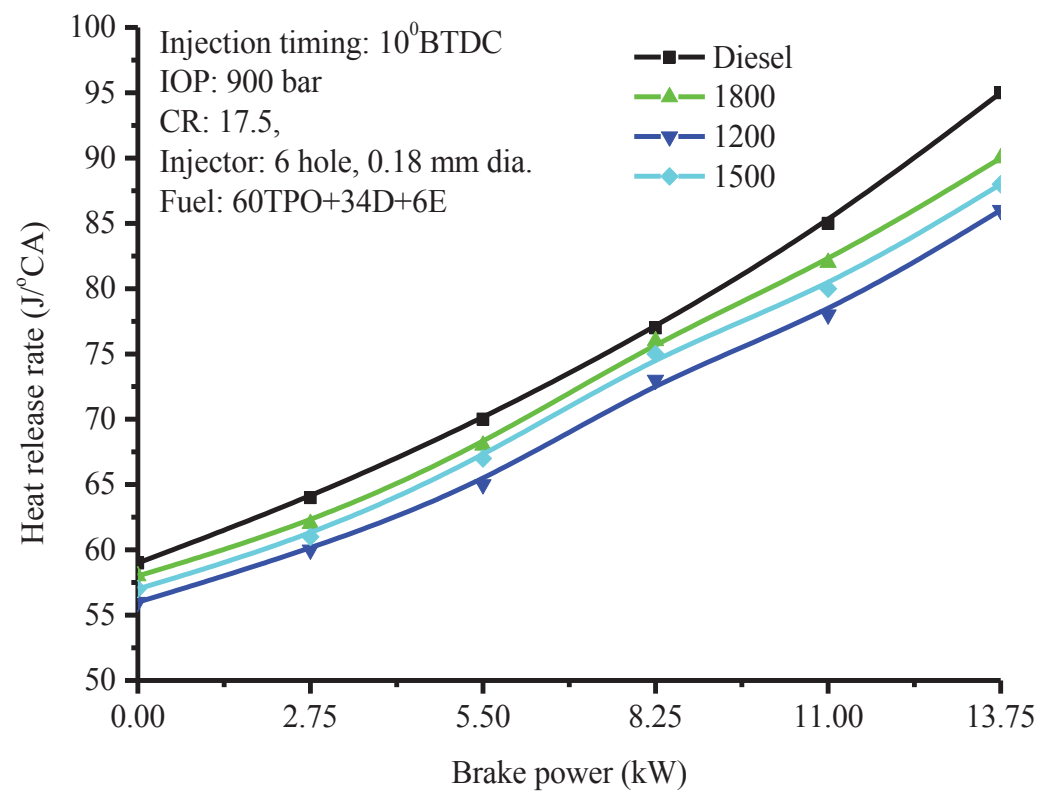



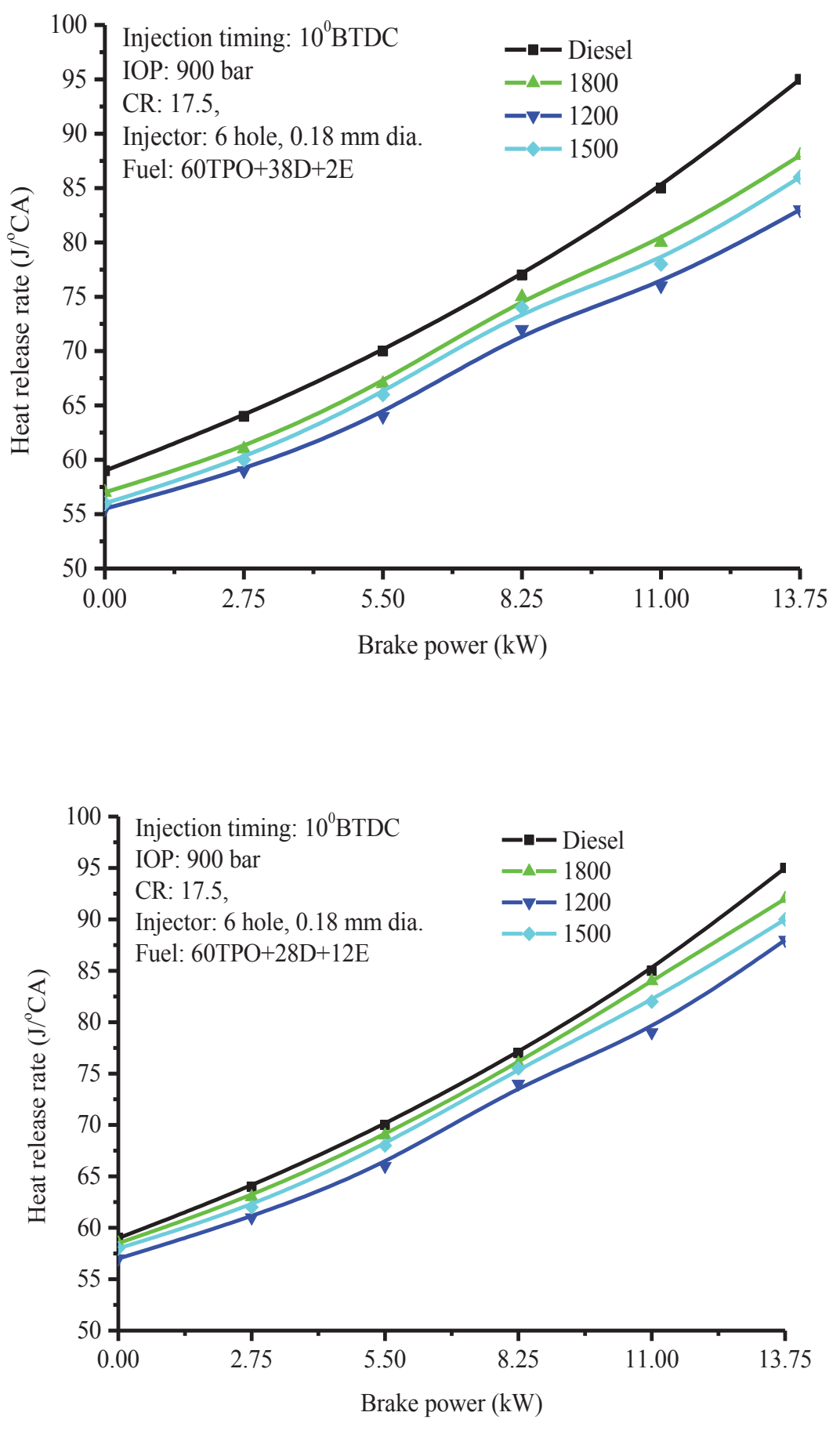

Figure 11. Effect of speed on Heat release rate of fuel blends at different loads. 


\section{CONCLUSIONS}

Experimental investigations were carried out on a multicylinder CRDI engine fueled with ethanol- pyrolysis oil and diesel blends using fixed volume of tyre pyrolysis oil in each combination selected. CRDI Engine performance, emission, and combustion characteristics were examined at different engine speeds and loads. The results achieved were compared with base diesel fuel operation results. The following conclusions are drawn from the results:

- $\quad$ TPO obtained from waste tyre through pyrolysis could be used as an alternative fuel along with ethanol and diesel.

- $\quad$ BTE increased with increase in load and speed but engine operation with blends selected showed lower performance in comparison to diesel. Further, BTE decreased with increase in ethanol proportion in blends.

- $\quad$ Engine yielded more $\mathrm{CO}, \mathrm{HC}$, and smoke emissions with all blends at different loads as compared to diesel but lowered to some extent with speed. However, NOx emissions with blends were less as compared to diesel.

- Combustion parameters like ID, PP, and HRR decreased with increase in ethanol content in the blend. However, CD increased with ethanol proportion in the blends.

Overall, it could be concluded that $2 \%$ of ethanol with $38 \%$ diesel and $60 \%$ TPO blend gave better results as compared to other combinations selected in the study with little penalty on BTE.

\section{ACKNOWLEDGMENT}

The authors extend their appreciation to the Deanship of Scientific Research at King Khalid University for funding this work through research groups program under grant number (R.G.P. 1/221/41).

\section{REFERENCES}

Asif, A., Mohammed K. \& Abdul R.R.K. 2018. Production of biodiesel from various sources and comparative engine performance studies by using different biodiesel blends. Journal of Engineering Research 6 (4): 1-21.

Ahoor, A.H.\& Navid, Z. A. 2014. Fuel production based on catalytic pyrolysis of waste tires as an optimized model. Energy Conversion and Management 87: 653-669.

Alenezi, R. \& Al-Anzi, B. 2013. Kinetic mechanism of transesterification of vegetable oil with supercritical methanol for Biodiesel production. Journal of Engineering Research 1: 81-96.

Al-lwayzy, S.H.; Yusaf, T. 2015. Combustion of microalgae oil and ethanol blended with diesel fuel. Energies, 8, 13985-13995.

An, H., Yang, W.M., Chou, S.K. \& Chua, K.J. 2012. Combustion and emissions characteristics of diesel engine fueled by biodiesel at partial load conditions. Applied energy 99: 363-371.

Antoniou, N.\& Zabaniotou, A. 2013. Features of an efficient and environmentally attractive used tyres pyrolysis with energy and material recovery. Renewable and Sustainable Energy Reviews 20: 539-558.

Armas, O., Hernandez, J.J. \& CardenasM.D. 2006. Reduction of diesel smoke opacity from vegetable oil methyl esters during transient operation. Fuel 85: 2427-2438.

Arya, S., Sharma, A., Rawat, M.\&Agrawal,A. 2020. Tyre pyrolysis oil as an alternative fuel: A review. Materials Today: Proceedings. 
Avulapati, M.M., Ganippa, L.C., Xia, J. \&Megaritis A. 2016.Puffing and micro-explosion of diesel-biodieselethanol blends. Fuel 166: 59-66.

Aydın, H. \&Cumali,I. 2012. Optimization of fuel production from waste vehicle tires by pyrolysis and resembling to diesel fuel by various desulfurization methods. Fuel 102: 605-612.

Aydın, H. \& Cumali, I. 2015. Analysis of combustion, performance and emission characteristics of a diesel engine using low sulfur tire fuel. Fuel 143: 373-382.

Banapurmath, N.R. \&, Tewari, P.G. 2010. Performance, combustion, and emissions characteristics of a singlecylinder compression ignition engine operated on ethanol-biodiesel blended fuels. Proceedings of the Institution of Mechanical Engineers, Part A: Journal of Power and Energy 224: 533-543.

Banapurmath, N.R.,Tewari, P.G. \& Hosmath, R.S. 2008. Performance and emission characteristics of a DI compression ignition engine operated on Honge, Jatropha and sesame oil methyl esters. Renewable energy 33: 1982-1988.

Beatrice, C., Napolitano, P., Guido, C. Injection parameter optimization by DoE of a light-duty diesel engine fed by Bio-ethanol/RME/diesel blend. Appl. Energy 2014, 113, 373-384.

Bucolo, M., Buscarino, A., Famoso, C., Fortuna, L. \& Frasca, M. 2019. Control of imperfect dynamical systems. Nonlinear Dynamics 98, 2989-2999

Clenci, A.; Niculescu, R.; Danlos, A.; Iorga-Simăn, V.; Trică, A. Impact of biodiesel blends and Di-Ethyl-Ether on the cold starting performance of a compression ignition engine. Energies 2016, 9, 284.

Dawodu, F.A.,Olubunmi,A., Xin, J., Zhang, S. \& Yan, D. 2014. Effective conversion of non-edible oil with high free fatty acid into biodiesel by sulphonated carbon catalyst. Applied energy 114: 819-826.

Elbaba, I.F. \& Williams, P.T. 2012. Two stage pyrolysis-catalytic gasification of waste tyres: Influence of process parameters. Applied Catalysis B: Environmental 125: 136-143.

Frigo, S., Seggiani, M., Puccini, M. \& Vitolo, S. 2014. Liquid fuel production from waste tyre pyrolysis and its utilisation in a Diesel engine. Fuel 116: 399-408.

Gadwal, S.B., Banapurmath, N.R, Kamoji, M.A., Rampure, P.B. \& Khandal, S.V. 2019. Performance and emission characteristic studies on CRDI diesel engine fuelled with plastic pyrolysis oil blended with ethanol and diesel. International Journal of Sustainable Engineering 12: 262-271.

García, M.; Gonzalo, A.; Sánchez, J.L.; Arauzo, J.; Peña, J.Á. Prediction of normalized biodiesel properties by simulation of multiple feedstock blends. Bioresour. Technol. 2010, 101, 4431-4439.

Hariharan, S., Murugan, S. \& Nagarajan, G, 2013. Effect of diethyl ether on Tyre pyrolysis oil fueled diesel engine. Fuel 104: 109-115.

Hayes, T. K., Savage L.D. \& Soreson S.C. 1986. Cylinder Pressure Data Acquisition and Heat Release Analysis on a Personal Computer. Society of Automotive Engineers, Paper No. 860029, USA.1986.

Hohenberg, G.F. 1979. Advanced approaches for heat transfer calculations. SAE paper 1979. 790825.

Hossain, A.K. \& Davies, P.A. 2013. Pyrolysis liquids and gases as alternative fuels in internal combustion engines-A review. Renewable and Sustainable Energy Reviews 21: 165-189.

How, H.G., Masjuki, H.H., Kalam M.A., Teoh Y.H. Engine performance, emission and combustion characteristics of a common-rail diesel engine fuelled with bioethanol as a fuel additive in coconut oil biodiesel blends. Energy Procedia 2014, 61, 1655-1659.

Hulwan, D. B., \& Joshi, S.V. 2011. Performance and Combustion Characteristics of a Multi-Cylinder DI Diesel Engine Running Diesel- Ethanol-Biodiesel Blends of High Ethanol Content. Applied Energy 88: 5042-5055. 
Indudhar, M., Banapurmath, N.R., Rajulu, K. G., Khan, T.M.Y, Manoj, E.K. 2019. Effects of single and split injection on the performance, emission and combustion attributes of a CRDI engine powered with diesel and honge biodiesel. Sustainable Energy \& Fuels 3: 2275-2286.

Jaichandar, S. \& Annamalai, K. 2013. Combined impact of injection pressure and combustion chamber geometry on the performance of a biodiesel fueled diesel engine. Energy 55: 330-339.

Jang, J.W., Yoo, T.S., Oh, J.H. \& Iwasaki,I. 1998. Discarded tire recycling practices in the United States, Japan and Korea. Resources, conservation and recycling 22: 1-14.

John, H. 1988. Internal combustion engine fundamentals, McGraw-Hill Science.

Khan, T.M.Y., Atabani., A.E., Badruddin, I.A., Badarudin, A., Khayoon, M.S. \& Triwahyono, S. 2014. Recent scenario and technologies to utilize non-edible oils for biodiesel production. Renewable and Sustainable Energy Reviews 37: 840-851.

Khandal, S.V., Sudershan, B., Raikar, V.A.,Khan, T.M.Y.\& Badruddin, I.A. (2020). An experimental-based artificial neural network performance study of common rail direct injection engine run on plastic pyrolysis oil. International Journal of Sustainable Engineering: 1-10.

Kwanchareon, P., Luengnaruemitchai, A. \& S J.In. 2007. Solubility of a diesel-biodiesel-ethanol blend, its fuel properties, and its emission characteristics from diesel engine. Fuel 86: 1053-1061.

Lee, S., Jang, Y., Kim, T.Y., Kang, K.Y., Kim, H. \& Lim, J. 2013. Performance and emission characteristics of a diesel engine fueled with pyrolysis oil-ethanol blend with diesel and biodiesel pilot injection. SAE International Journal of Fuels and Lubricants 6: 785-793.

Lee, S.K. \&Young,T. 2015. Feasibility study of using wood pyrolysis oil-ethanol blended fuel with diesel pilot injection in a diesel engine. Fuel 162: 65-73.

Manjunath, N., Rajashekhar, C.R., Khan, T.M.Y., Badruddin, I.A., Kamangar, S. \& Khandal, S.V. 2019. Augmented Turbulence for Progressive and Efficient Combustion in Biodiesel-Diesel Engine. Arabian Journal for Science and Engineering 44: 7957-7966.

Martínez, J.D., Felipe,C., Cardona-U.N., Arenas, C.N. \& Munoz, L.D. 2020. Waste tire valorization by intermediate pyrolysis using a continuous twin-auger reactor: Operational features. Waste management 113: 404-412.

Martínez, J. D., Jose, R.F., Sanchez, V.J., Murillo, R. \& Garcia, T. 2014.Performance and emissions of an automotive diesel engine using a tire pyrolysis liquid blend. Fuel 115: 490-499.

McNeil, J., Day, P. \& Sirovski, F. 2012. Glycerine from biodiesel: The perfect diesel fuel. Process Safety and Environmental Protection 90: 180-188.

Montajir, R.M., Tsunemoto, H., Ishitani, H. \& Minami, T. 2000. Fuel spray behavior in a small DI diesel engine: effect of combustion chamber geometry, SAE Technical Paper.

Murugan, S.,Ramaswamy, M.C. \& Nagarajan, G. 2008. The use of tyre pyrolysis oil in diesel engines. Waste management 28: 2743-2749.

Sayin, C. 2010. Engine performance and exhaust gas emissions of methanol and ethanol-diesel blends. Fuel 89: 3410-3415.

Seljak, T.O., Samuel R. \& Katrasnik, T. 2015. Combustion characteristics of tire pyrolysis oil in turbo charged compression ignition engine. Fuel 150: 226-235.

Sharma, A. \& Murugan, S. 2013. Investigation on the behaviour of a DI diesel engine fueled with Jatropha Methyl Ester (JME) and Tyre Pyrolysis Oil (TPO) blends. Fuel 108: 699-708. 
Sharma, A. \& Murugan, S. 2015 (a). Combustion, performance and emission characteristics of a DI diesel engine fuelled with non-petroleum fuel: a study on the role of fuel injection timing. Journal of the Energy Institute 88: $364-375$.

Sharma, A. \& Murugan, S. 2015 (b). Potential for using a tyre pyrolysis oil-biodiesel blend in a diesel engine at different compression ratios. Energy Conversion and Management 93: 289-297.

Sjoberg, M.D. \& John, E. 2005. Effects of engine speed, fueling rate, and combustion phasing on the thermal stratification required to limit HCCI knocking intensity. SAE transactions: 1472-1486.

Soudagar, M.E.M., Nik-Nazri,N.G., Kalam, M.A., Badruddin, I. A., Banapurmath, N.R., Khan, T.M.Y., Bashir, M.N., Akram, N., Farade, R. \& Afzal, A. 2019. The effects of graphene oxide nanoparticle additive stably dispersed in dairy scum oil biodiesel-diesel fuel blend on CI engine: performance, emission and combustion characteristics. Fuel 257: 116015.

Subbaiah, G.V.; Gopal, K.R.; Hussain, S.A.; Prasad, B.D.; Reddy, K.T.; Pradesh, A. Rice Bran Oil Biodiesel As an Additive in Diesel-Ethanol Blends for Diesel Engines. Int. J. Recent Res. Appl. Stud. 2010.

Sudershan, B.G., Kamoji., M.A., Rampure, P.B., Banapurmath, N.R. \& Khandal, S.V. 2018a.Experimental Studies on the Use of Pyrolysis Oil for Diesel Engine Applications and Optimization of Engine Parameters of Injection Timing, Injector Opening Pressure and Injector Nozzle Geometry. Arabian Journal for Science and Engineering 43: 4517-4530.

Sudershan, B.G., Nagaraj, R.B., Kamoji, M.A., Rampure, P.B. \& Sanjeevkumar V.K. 2018b. Experimental investigation of a CRDI engine in terms of performance and emission under the effect of injection strategy using a moderate percentage of plastic pyrolysis oil and its blends with diesel and ethanol. Biofuels: 1-15.

Tomic, M.D., Savin L.D., Micic, R.D., Simikic M.D. \& Furman T.F. 2013. Effects of fossil diesel and biodiesel blends on the performances and emissions of agricultural tractor engines. Thermal Science 17: 263-278.

Tutak, W.; Jamrozik, A.; Pyrc, M.; Sobiepan'ski, M. Investigation on combustion process and emissions characteristic in direct injection diesel engine powered by wet ethanol using blend mode. Fuel Process. Technol. 2016, 149, 86-95.

Van de Beld, B., Holle, E.\& Florijn, J. 2013. The use of pyrolysis oil and pyrolysis oil derived fuels in diesel engines for CHP applications. Applied energy 102: 190-197.

Wang, H.,Xu; H. \&Xuan, X. 2010. Review of Waste Tire Reuse\& Recycling in China-current situation, problems and countermeasures. Advances in Natural Science 2: 31-39. 